\title{
FAKTOR YANG MEMPENGARUHI KEPUTUSAN NASABAH MENABUNG DI BANK MUAMALAT INDONESIA
}

\author{
Deftyan Hadi Pratita \\ Mahasiswa Program Studi S1 Ekonomi Islam-Fakultas Ekonomi dan Bisnis-Universitas \\ Airlangga \\ Email: 2010.d.h.pratita@student.unair.ac.id \\ Sri Herianingrum \\ Departemen Ekonomi Syariah-Fakultas Ekonomi dan Bisnis-Unversitas Airlangga \\ Email: sri.herianingrum@feb.ac.id
}

\begin{abstract}
This study used a quantitative approach using factor exploratory analysis. In this study, the characteristic of the population were customers' of Bank Muamalat Indonesia in Surabaya. Pre eliminary test was conducted by using focus group discussion to 10 customers, while for the main test used simple random sampling with probability sampling as the sampling method towards 100 customers.

According to the result, there are eight factors that influence customers' saving decision in Bank Muamalat Indonesia. Those factors are the reduction result from the factor analysis process. Those eight factors are services provider, normative perception, clear information, process, the product's syariah value, referrals, environment suitability and office layout design.
\end{abstract}

Keywords : customers' saving decision, Syariah Bank, Bank Muamalat Indonesia, Factor Analysis

I. PENDAHULUAN

A. Latar Belakang

Perkembangan peran perbankan syariah di Indonesia tidak terlepas dari sistem perbankan di Indonesia secara umum. Sistem perbankan diatur dalam UU. No 10 tahun 1998 dimana bank umum adalah bank yang melaksanakan kegiatan usaha secara konvensional atau dengan prinsip syariah yang kegiatannya memberikan jasa dalam lalu lintas pembayaran. Peran Bank Syariah dalam memacu pertumbuhan perekonomian daerah semakin strategis dalam rangka mewujudkan struktur perekonomian yang semakin berimbang. Dukungan terhadap pengembangan perbankan syariah juga diperlihatkan dengan adanya "dual banking system", artinya bank konvensional diperkenankan untuk membuka unit usaha perbankan syariah (Ratnawati, 2010).

Penelitian ini akan dilakukan di Bank Muamalat Indonesia Kota Surabaya dengan objek penelitian nasabah bank muamalat indonesia. Alasan peneliti memilih Bank Muamalat Indonesi sebagai subyek penelitian karena mempertimbangkan slogan Bank Muamalat "pertama murni syariah" yang mengusung citra bahwa Bank Muamalat Indonesia merupakan bank syariah pertama yang berdiri di indonesia.

\section{B. Rumusan Masalah}

Faktor apa saja yang mempengaruhi keputusan nasabah menabung di Bank Muamalat Indonesia?

\section{Tujuan Penelitian}

[1] Jurnal ini merupakan bagian Skripsi Deftyan Hadi Pratita NIM 041014084 yang diuji pada tanggal 2 Mei 2017 
Pratita, et al/Jurnal Ekonomi Syariah Teori dan Terapan Vol.5 No.7 Juli 2018: 522-540; FAKTOR YANG MEMPENGARUHI KEPUTUSAN NASABAH MENABUNG DI BANK MUAMALAT INDONESIA

Tujuan dalam penelitian ini adalah untuk mengetahui faktor apa saja yang mempengaruhi keputusan nasabah untuk menabung di Bank Muamalat Indonesia.

\section{LANDASAN TEORI}

\section{A. Bank Syariah}

Bank syariah dibedakan kedalam dua pengertian, yaitu bank islam dan bank yang beroperasi dengan prinsip syariah islam (Perwataatmadja dan Antonio, 1992:1). Bank islam adalah (1) bank yang beroperasi sesuai dengan prinsip - prinsip syariah islam; bank yang tata cara beroperasinya mengacu kepada ketentuan - ketentuan al-Qur'an dan Hadits; sementara bank yang beroperasi sesuai prinsip syariah islam adalah bank yang dalam beroperasinya itu mengikuti ketentuan - ketentuan syariah islam, khususnya yang menyangkut tata cara bermuamalat secara islami. Dalam tata cara bermuamalat itu dijauhi praktik -praktik yang dikhawatirkan mengandung unsur - unsur riba untuk diisi dengan kegiatan - kegiatan investasi atas dasar bagi hasil dan pembiayaan perdagangan (Perwataatmadja dan Antonio, 1992:1-2 )

\section{B. Nasabah Bank Syariah}

Berdasarkan Undang-Undang Republik Indonesia no 21 tahun 2008 tentang Perbankan Syariah. Nasabah adalah pihak yang menggunakan jasa Bank Syariah dan / atau Unit Usaha Syariah (UUS). Dalam Bank syariah / UUS nasabah dibagi menjadi 3 golongan :

1. Nasabah Penyimpan
2. Nasabah Investor

3. Nasabah Penerima Fasilitas

\section{Pemasaran Islam}

Ratnasari (2009:33) mengatakan bahwa pemasaran syariah adalah fungsi organisasi dan seperangkat proses untuk menciptakan, mengkomunikasikan dan memberikan nilai syariah kepada pelanggan, dengan cara yang menguntungkan organisasi dan para pemangku kepentingan, yang dalam keseluruhan prosesnya harus sesuai dengan prinsip-prinsip muamalah dalam Islam, untuk mendapatkan ridho Allah SWT

\section{Perilaku Konsumen Muslim}

perilaku konsumen dalam islam berasal dari akhlak yang berarti budi pekerti, peringai, tingkah laku, dan tabiat. Akhlak merupakan suatu kondisi atau sifat yang telah meresap dalam jiwa dan menjadi kepribadian hingga timbul berbagai macam perbuatan secara spontan, tanpa dibuat-buat dan tanpa memerlukan pemikiran (Asmaran, 1992 dalam Moediarso, 2012).

\section{E. Faktor yang Mempengaruhi Keputusan}

1. Faktor Keimanan

Muflih (2006:12) menyatakan bahwa proses keputusan konsumen muslim dalam konsumsi tidak dapat dipisahkan dari peranan keimanan. Keimanan menjadi tolak ukur yang memberikan cara pandang dunia dalam mempengaruhi kepribadian.

2. Faktor Strategi Pemasaran 
Zeithaml

(2000:

mengemukakan konsep bauran pemasaran tradisional terdiri dari $4 \mathrm{P}$ yaitu product, price, place, promotion. Sementara itu, untuk pemasaran jasa perlu diperluas dengan penambahan unsur nontraditional marketing mix, yaitu people, physical evidence, process, sehingga menjadi 7P. Masingmasing dari tujuh unsur bauran pemasaran tersebut saling berhubungan dan tegantung satu sama lainnya dan mempunyai suatu bauran yang optimal sesuai dengan karakteristik segmennya.

3. Faktor Lingkungan Sosial

Kottler dan Keller (2009:166)
menjelaskan bahwa, faktor
lingkungan merupakan faktor
eksternal yang mempengaruhi
keputusan konsumen dalam
pembelian suatu produk, faktor-
faktor tersebut meliputi:
a. Kebudayaan (culture)
b. Sub Budaya (subculture)
c. Kelompok Tatap Muka
(face to face group)

3. Faktor Individu

Assael (1998:84) menjelaskan bahwa, faktor individu didefinisikan sebagai karakteristik psikologis seseorang yang berbeda dengan orang lain yang menyebabkan tanggapan yang relatif konsisten dan bertahan lama terhadap lingkungan.

\section{METODE PENELITIAN}

\section{A. Pendekatan Penelitian}

Pendekatan yang digunakan dalam penelitian ilmiah ini adalah pendekatan kuantitatif . Sugiyono (2010:8) menyatakan bahwa penelitian kuantitatif menitik beratkan pada pengujian hipotesis, data yang digunakan harus terukur, dan akan menghasilkan kesimpulan yang dapat digeneralisasikan. Pendekatan ini lebih sering berupaya mengukur suatu konsep variabel), sehingga lebih mudah dipahami secara statistik. Teknik analisa yang digunakan dalam penelitian ini adalah analisis faktor (factor analysis).

\section{B. Identifikasi Variabel}

Dalam penelitian yang menggunakan analisis faktor, tidak diidentifikasikan variabel bebas maupun variabel terikat. Pada penelitian ini dirumuskan 42 indikator yang akan direduksi menjadi faktor atau variabel. Variabel yang akan diteliti adalah keputusan nasabah menabung di Bank Muamalat Indonesia Kota Surabaya.

\section{Definisi Operasional Variabel}

Penelitian ini bertujuan untuk menggali faktor- faktor yang mempengaruhi keputusan nasabah menabung di Bank Muamalat Indonesia cabang Surabaya, maka indikator nasabah menabung di Bank Muamalat Indonesia cabang Surabaya diperoleh 
Pratita, et al/Jurnal Ekonomi Syariah Teori dan Terapan Vol.5 No.7 Juli 2018: 522-540; FAKTOR YANG MEMPENGARUHI KEPUTUSAN NASABAH MENABUNG DI BANK MUAMALAT INDONESIA

dari hasil proses penggalian data melalui wawancara. Dari proses wawancara tersebut menghasilkan beberapa variabel yang mempengaruhi keputusan nasabah menabung di Bank Muamalat Indonesia cabang Surabaya beserta definisi operasional yang dianalisis adalah sebagai berikut:

1. Pemahaman produk tabungan perbankan Halal $\left(X_{1}\right)$ adalah pemahaman yang dimiliki oleh nasabah mengenai produk tabungan yang ditawarkan BMI adalah Halal.

2. Pemahaman produk tabungan perbankan bebas Riba' $\left(\mathrm{X}_{2}\right)$ adalah pemahaman yang dimiliki oleh nasabah mengenai produk tabungan yang ditawarkan BMI adalah bebas Riba'.

3. Pemahaman kesesuaian produk tabungan dengan standar muamalah di bidang perbankan $\left(X_{3}\right)$ adalah pemahaman yang dimiliki oleh nasabah mengenai produk tabungan yang ditawarkan oleh BMI sudah sesuai syariah dalam ber-muamalah.

4. Ketertarikan nasabah pada produk tabungan BMI $\left(X_{4}\right)$ adalah nasabah merasa tertarik kepada salah satu diantara produk tabungan yang dikeluarkan oleh BMI.

5. Variasi produk tabungan BMI yang sesuai dengan kebutuhan nasabah $\left(X_{5}\right)$ adalah nasabah merasa bahwa produk yang dihasilkan oleh BMI sesuai kebutuhan nasabah.

6. Informasi mengenai produk tabungan BMI mudah diakses oleh nasabah $\left(X_{6}\right)$ adalah nasabah merasa mudah memperoleh informasi mengenai produk tabungan BMI.

7. Ketetapan mengenai biaya administrasi produk tabungan BMI (X7) adalah nasabah masih menganggap bahwa biaya administrasi produk tabungan BMI masih dalam batas wajar.

8. Ketetapan mengenai setoran awal oleh BMI (X8) adalah nasabah tidak merasa keberatan dengan setoran awal yang ditetapkan oleh BMI .

9. Ketetapan mengenai saldo minimum oleh BMI ( $\left.X_{9}\right)$ adalah nasabah tidak merasa keberatan dengan saldo minimum yang harus dimiliki dalam rekening yang ditetapkan oleh BMI.

10. Lokasi yang strategis dan mudah dijangkau $\left(X_{10}\right)$ adalah nasabah merasa bahwa lokasi Kantor BMI strategis dan mudah dijangkau.

11. Lokasi kantor yang dekat dengan keramaian dan fasilitas umum (X11) adalah nasabah merasa bahwa kantor BMI dekat dengan keramaian dan fasilitas umum.

12. Distribusi mesin ATM BMI ( $\left.\mathrm{X}_{12}\right)$ adalah nasabah merasa mudah 
untuk menemui ATM BMI karena terdistribusi dengan baik.

13. Brosur produk tabungan BMI menarik $\left(X_{13}\right)$ adalah nasabah tertarik saat melihat brosur produk tabungan BMI.

14. Kejelasan informasi yang dituliskan pada brosur BMI $\left(\mathrm{X}_{14}\right)$ adalah nasabah mendapatkan informasi yang jelas dari brosur produk tabungan BMI.

15. Web produk tabungan BMI menarik $\left(X_{15}\right)$ adalah nasabah tertarik saat melihat Web mengenai produk tabungan BMI.

16. Kejelasan informasi yang dituliskan pada Web BMI (X16) adalah nasabah mendapatkan informasi yang jelas dari Web mengenai produk tabungan BMI secara On-Line.

17. BMI bekerjasama dengan merchant dan memberikan promo untuk nasabah $\left(X_{17}\right)$ adalah nasabah merasa tertarik dengan poromo yang diberikan BMI dengan bekerjasama dengan merchant.

18. Keramahan karyawan $\mathrm{BMI}\left(\mathrm{X}_{18}\right)$ adalah nasabah merasa karyawan BMI melakukan pengenalan diri sebelum bertransaksi dengan ramah.

19. Penampilan karyawan BMI (X19) adalah penampilan karyawan / karyawati BMI adalah sopan dan menarik dimata nasabah.
20. Cara karyawan BMI menjelaskan produk $\left(\mathrm{X}_{20}\right)$ adalah nasabah merasa bahwa karyawan / karyawati BMI menjelaskan mengenai produk tabungan dengan sabar dan telaten.

21. Ketanggapan karyawan $\mathrm{BMI}\left(\mathrm{X}_{21}\right)$ adalah nasabah merasa bahwa karyawan BMl tanggap akan pertanyaan dan kebutuhan nasabah.

22. Ketanggapan dan ketelitian karyawan BMI $\left(\mathrm{X}_{22}\right)$ adalah nasabah merasa bahwa karyawan BMI tanggap dan teliti terhadap keluhan atau kendala yang dialami oleh nasabah.

23. Kenyamanan dalam ruang tunggu kantor BMl $\left(\mathrm{X}_{23}\right)$ adalah nasabah merasa nyaman saat berada dalam ruang tunggu kantor BMI.

24. Lahan Parkir kantor BMI yang luas dan nyaman $\left(\mathrm{X}_{24}\right)$ adalah nasabah merasa nyaman saat memarkir kendaraannya karena lahan parkir kantor BMI luas.

25. Penataan ruangan kantor BMl $\left(X_{25}\right)$ adalah nasabah merasa tata ruang kantor BMI adalah rapih dan nyaman.

26. Penampilan kantor BMl yang menarik $\left(X_{26}\right)$ adalah nasabah tertarik dengan kantor BMl yang di design dengan uansa ungu dan hijau.

27. Proses saat pembukaan rekening Tabungan BMI $\left(\mathrm{X}_{27}\right)$ adalah 
Pratita, et al/Jurnal Ekonomi Syariah Teori dan Terapan Vol.5 No.7 Juli 2018: 522-540; FAKTOR YANG MEMPENGARUHI KEPUTUSAN NASABAH MENABUNG DI BANK MUAMALAT INDONESIA

nasabah merasakan kemudahan saat melakukan proses pembukaan rekening tabungan BMI.

28. Proses pendaftaran internetbanking BMI $\left(\mathrm{X}_{28}\right)$ adalah nasabah merasa mudah saat melakukan pendaftaran internet-banking.

29. Antrian saat menuju customer service / teller di kantor BMI ( $\left.\mathrm{X}_{29}\right)$ adalah nasabah merasa antrian saat melakukan transaksi di customer service / teller cepat.

30. Proses transaksi melalui internetbanking BMI $\left(\mathrm{X}_{30}\right)$ adalah nasabah merasa transaksi melalui internetbanking BMI cepat dan mudah.

31. Kesesuaian produk tabungan BMI dan kebutuhan ekonomi $\left(X_{31}\right)$ adalah nasabah merasa bahwa adanya kesesuaian anatara kebutuhan ekonomi dengan fitur dari produk tabungan BMI.

32. Kesesuaian produk tabungan BMI dan tujuan kevangan $\left(X_{32}\right)$ adalah nasabah merasa bahwa adanya kesesuaian anatara tujuan keuangan dengan fitur dari produk tabungan BMI.

33. Kesesuaian pemahaman bank syariah dengan BMI $\left(X_{33}\right)$ adalah nasabah menabung karena merasa adanya kesesuaian antara BMI dengan pemahaman mengenai Bank Syariah

34. Kesesuaian antara BMI dengan ekspektasi Bank Syariah $\left(X_{34}\right)$ adalah nasabah menabung di
BMI karena merasa BMI sesuai dengan ekspektasi mengenai Bank Syariah.

35. Kesesuaian antara pribadi yang Islami dan BMI $\left(X_{35}\right)$ adalah nasabah merasa bahwa BMI sesuai dengan pribadi mereka yang Islami.

36. Sesuai dengan ajaran agama Islam $\left(X_{36}\right)$ adalah nasabah menabung di BMI karena merasa sesuai dengan jaran agama Islam.

37. Ada keluarga / kerabat dekat yang menjadi nasabah $\left(X_{37}\right)$ adalah nasabah menabung di BMI karena adanya keluarga / kerabat dekat yang sudah menjadi nasabah BMI.

38. Keinginan menjalan perilaku hidup yang Islami $\left(X_{38}\right)$ adalah nasabah menabung di BMl karena ingin menjalani perilaku hidup yang Islami.

39. Pengaruh lingkungan kerja / sekolah / kuliah (X39) adalah nasabah menabung di BMI karena pengaruh lingkungan kerja / sekolah / kuliah.

40. Terbiasa akan lingkungan yang Islami $\left(\mathrm{X}_{40}\right)$ adalah nasabah menabung di BMl karena sudah terbiasa dengan lingkungan sekitar yang Islami.

41. Kesesuaian dengan strata sosial $\left(X_{41}\right)$ adalah nasabah menabung di BMI karena sesuai dengan strata sosial mereka. 
Pratita, et al/Jurnal Ekonomi Syariah Teori dan Terapan Vol.5 No.7 Juli 2018: 522-540; FAKTOR YANG MEMPENGARUHI KEPUTUSAN NASABAH MENABUNG DI BANK MUAMALAT INDONESIA

42. Sesuai dengan jabatan $\left(\mathrm{X}_{42}\right)$ adalah nasabah menabung di BMI karena merasa sesuai dengan jabatan mereka.

Data penelitian dikumpulkan dengan menyebar kuesioner dan jawaban para responden akan diolah dengan menggunakan skala Likert yang terdiri dari, Sangat Setuju (skor 4), Setuju (skor 3), Tidak Setuju (skor 2), Sangat Tidak Setuju (1).

\section{Populasi Sampel}

Karakteristik populasi dalam penelitian ini adalah nasabah yang menabung di Bank Muamalat Indonesia di Kota Surabaya. Karena populasi besar dan keterbatasan peneliti maka peneliti dapat menggunakan sampel yang diambil dari populasi itu. Untuk itu sampel yang diambil dari populasi harus benarbenar mewakili (representatif). Menurut Aaker (1997:12) menyarankan bahwa jumlah sampel harus cukup besar sehingga jika dibagi dengan kelompokkelompok akan mempunyai ukuran sampel minimal 100 atau lebih.

\section{E. Metode Pengambilan Sampel}

Pada penelitian ini, peneliti mendapatkan responden dengan cara menyebar kuesioner pada nasabah produk yang menabung di Bank Muamalat Indonesia - Surabaya.

Penelitian ini menggunakan 42 indikator, dan dilakukan kepada 100 responden yang merupakan nasabah aktif produk tabungan Bank Muamalat
Indonesia. Menurut Sampel penelitian ini yaitu nasabah yang menabung di Bank Muamalat Indonesia cabang Surabaya dan telah menjadi nasabah lebih dari 3 bulan terhitung sejak 22 Juli 2016.

\section{F. Teknik Analisis}

$$
\text { Teknik analisis data yang }
$$
digunakan adalah analisis faktor eksploratori yang merupakan suatu teknik statistik multivariat untuk mengurangi (mereduksi) dan meringkas semua variabel terikat dan saling berketergantungan. Hubungan antara satu indikator dengan indikator yang lain akan diuji untuk diidentifikasikan dimensi atau faktornya (Malhotra, 1996).

Model analisis faktor secara umum:

$\mathrm{Xi}=\mathrm{AilF1}+\mathrm{Ai} 2 \mathrm{~F} 2+\mathrm{Ai} 3 \mathrm{~F} 3+. .+\mathrm{AimFm}+$ ViUi

Dimana:

$\mathrm{Xi}=$ standarisasi indikator ke-1

Aij = standarisasi koefisien regresi berganda indikator 1 pada faktor biasa j

F2 = faktor biasa

$\mathrm{Vi}=$ standarisasi koefisien regresi dari indikator 1 pada unik $\mathrm{i}$

Ui $\quad$ faktor unik untuk indikator 1

$\mathrm{m} \quad$ = banyaknya faktor biasa

\section{G. Uji Validitas}

Validitas alat ukur yang digunakan adalah teknik corrected item-total correlation, dengan cara mengkorelasi tiap item dengan skor totalnya. Kriteria valid adalah bila korelasi $r>0$. Jadi 
Pratita, et al/Jurnal Ekonomi Syariah Teori dan Terapan Vol.5 No.7 Juli 2018: 522-540; FAKTOR YANG MEMPENGARUHI KEPUTUSAN NASABAH MENABUNG DI BANK MUAMALAT INDONESIA

apabila korelasi antara butir dengan skor total $<0,3$ maka butir dalam instrument tersebut dinyatakan valid (Sugiyono,2010:126). Suatu skala pengukuran disebut valid apabila melakukan apa yang seharusnya dilakukan dan mengukur apa yang seharusnya diukur (Kuncoro, 2003:151). Skala pengukuran menjadi tidak berguna atau bermanfaat apabila skala pengukuran tidak valid, karena tidak mengukur apa yang seharusnya diukur atau tidak melakukan apa yang seharusnya dilakukan.

\section{H. Uji Reliabilitas}

Pengertian reliabilitas menurut Nazir (2003:133) adalah menyangkut ketepatan alat ukur. Suatu alat ukur mempunyai reliabilitas tinggi atau dapat dipercaya apabila alat ukur itu mantap atau stabil, dapat diandalkan dan dapat diramalkan. Suatu alat ukur yang mantap tidak berubah-ubah pengukurannya dan dapat diandalkan karena penggunaan alat ukur tersebut berkali-kali dan menghasilkan hasil yang sama. Metode cronbach alpha digunakan untuk memeriksa reabilitas instrument. Keseluruhan indikator dianggap sudah cukup reliabel bilamana $a a \geq 0,6$. Pengujian instrument penelitian dilakukan dengan instrumen komputer melalui program SPSS release 18.

\section{Analisis Data}

pada penelitian ini analisis faktor yang digunakan bertujuan untuk mengeksplorasi indikator-indikator baru yang membentuk suatu faktor. Model atau teknik analisis faktor, menggunakan Principal Component Analysis (PCA). Hasil perhitungan menurut Maholtra (1996:646) terdapat beberapa kunci statistik, antara lain :

1. Barlett's test of sphericity, yaitu yang digunakan untuk menguji interdependensi antara butir-butir yang menjadi indikator suatu indikator atau faktor. Analisis ini bermaksud untuk mengetahui indikator yang tidak berkolerasi satu dengan yang lainnya (colinearity) dalam populasi. Apabila ternyata terbukti ada indikator yang tidak berkorelasi maka salah satu dari indikator tersebut tidak perlu dianalisis.

2. Keiser-Meyer Olkin (KMO) measure of sampling adequancy, adalah angka indeks untuk membandingkan antara besarnya koefisien korelasi observasi dengan besarnya koefisien korelasi parsial. Apabila nilai KMO kecil (kurang dari 0,5) menunjukkan bahwa korelasi antar indikator tidak dapat menjelaskan indikator lain dan analisis faktor tidak sesuai untuk diterapkan.

Hasil perhitungan selengkapnya adalah sebagai berikut :

Tabel 1.

Kaiser-Meyer Olkin (KMO) Measure of Sampling Adequancy

\begin{tabular}{|c|c|c|}
\hline \multicolumn{2}{|c|}{$\begin{array}{c}\text { Kaiser-Meyer-Olkin Measure of } \\
\text { Sampling Adequacy }\end{array}$} &, 862 \\
\hline Bartlett's & Approx. Chi- & 3324,275 \\
\hline
\end{tabular}


Pratita, et al/Jurnal Ekonomi Syariah Teori dan Terapan Vol.5 No.7 Juli 2018: 522-540; FAKTOR YANG MEMPENGARUHI KEPUTUSAN NASABAH MENABUNG DI BANK MUAMALAT INDONESIA

\begin{tabular}{|c|c|c|}
\hline Test of & Square & \\
\cline { 2 - 3 } Sphericity & Df & 666 \\
\cline { 2 - 3 } & Sig. &, 000 \\
\hline
\end{tabular}

Sumber : Hasil penelitian, 2016 (diolah)

Nilai Keiser-Meyer Olkin (KMO) measure of sampling adequancy hasil perhitungan adalah $0,862>0,5$ yang berarti bahwa korelasi antar indikator dapat menjelaskan indikator lain dan analisis faktor sesuai untuk dijadikan alat analisis.

3. Correlation matrix, yaitu matrik korelasi yang merupakan hasil korelasi antar butir yang menunjukkan koefisien korelasi (r) antara butir satu dengan butir yang lainnya, yang dapat atau tidak dapat dimasukkan dalam analisis pada hasil analisis faktor dalam tabel anti image correlation. Anti-image correlation merupakan matriks korelasi parsial antar variabel. Diagonal matriks memperlihatkan pengukuran kecukupan sampel untuk masingmasing variabel. Oleh karena itu, variabel yang memiliki nilai diagonal $<0,5$ harus dibuang karena menandakan bahwa data tidak cukup. Berikut adalah rangkuman hasil nilai anti image correlation dapat dilihat pada Tabel 2

Tabel 2
Nilai Korelasi Anti image Ketiga

\begin{tabular}{|c|c|c|c|c|c|}
\hline $\begin{array}{l}\text { Faktor } / \\
\text { Indikator }\end{array}$ & $\begin{array}{l}\text { Nilai korelasi } \\
\text { (Anti image) }\end{array}$ & Keputusan & $\begin{array}{l}\text { Faktor } / \\
\text { Indikator }\end{array}$ & $\begin{array}{c}\text { Nilai korelasi } \\
\text { (Anti image) }\end{array}$ & Keputusan \\
\hline $\mathrm{X}_{1}$ & 0,835 & Dapat dianalisis & $\mathrm{X}_{25}$ & 0,721 & Dapat dianalisis \\
\hline $\mathrm{X}_{2}$ & 0,892 & Dapat dianalisis & $\mathrm{X}_{26}$ & 0,892 & Dapat dianalisis \\
\hline $\mathrm{X}_{3}$ & 0,895 & Dapat dianalisis & $\mathrm{X}_{27}$ & 0,826 & Dapat dianalisis \\
\hline $\mathrm{X}_{5}$ & 0,897 & Dapat dianalisis & $\mathrm{X}_{28}$ & 0,837 & Dapat dianalisis \\
\hline $\mathrm{X}_{6}$ & 0,880 & Dapat dianalisis & $\mathrm{X}_{29}$ & 0,788 & Dapat dianalisis \\
\hline $\mathrm{x}_{7}$ & 0,885 & Dapat dianalisis & $\mathrm{X}_{30}$ & 0,788 & Dapat dianalisis \\
\hline $\mathrm{X}_{8}$ & 0,860 & Dapat dianalisis & $\mathrm{X}_{31}$ & 0,813 & Dapat dianalisis \\
\hline $\mathrm{X}_{9}$ & 0,832 & Dapat dianalisis & $\mathrm{X}_{32}$ & 0,853 & Dapat dianalisis \\
\hline $\mathrm{X}_{13}$ & 0,872 & Dapat dianalisis & $\mathrm{X}_{33}$ & 0,909 & Dapat dianalisis \\
\hline $\mathrm{X}_{14}$ & 0,920 & Dapat dianalisis & $\mathrm{X}_{34}$ & 0,930 & Dapat dianalisis \\
\hline $\mathrm{X}_{15}$ & 0,800 & Dapat dianalisis & $\mathrm{X}_{35}$ & 0,875 & Dapat dianalisis \\
\hline $\mathrm{X}_{16}$ & 0,881 & Dapat dianalisis & $\mathrm{X}_{36}$ & 0,885 & Dapat dianalisis \\
\hline $\mathrm{X}_{17}$ & 0,815 & Dapat dianalisis & $\mathrm{X}_{37}$ & 0,626 & Dapat dianalisis \\
\hline $\mathrm{X}_{18}$ & 0,886 & \begin{tabular}{|l|} 
Dapat dianalisis \\
\end{tabular} & $\mathrm{X}_{38}$ & 0,917 & Dapat dianalisis \\
\hline $\mathrm{X}_{19}$ & 0,859 & Dapat dianalisis & $\mathrm{X}_{39}$ & 0,571 & Dapat dianalisis \\
\hline $\mathrm{X}_{20}$ & 0,886 & Dapat dianalisis & $\mathrm{X}_{40}$ & 0,846 & Dapat dianalisis \\
\hline $\mathrm{X}_{21}$ & 0,917 & Dapat dianalisis & $\mathrm{X}_{41}$ & 0,572 & Dapat dianalisis \\
\hline $\mathrm{X}_{22}$ & 0,893 & \begin{tabular}{|l|} 
Dapat dianalisis \\
\end{tabular} & $\mathrm{X}_{42}$ & 0.650 & Dapat dianalisis \\
\hline $\mathrm{X}_{23}$ & 0,901 & Dapat dianalisis & & & \\
\hline
\end{tabular}

Sumber : Hasil penelitian, 2016 (diolah)

Pada uji anti image korelasi pertama dan kedua belum mendapatkan seluruh indikator bernilai 0,5 sehingga dilakukan eliminasi indikator kembali sampai didapatkan seluruh indikator memiliki nilai diatas 0,5 .

Hasil perhitungan pada Tabel 3 menunjukkan nilai korelasi tertinggi pada indikator ke 34 dengan nilai 0,930. Idan nilai korelasi terendah 0,571 pada indikator ke 39.

Tabel 3

Nilai Communalities

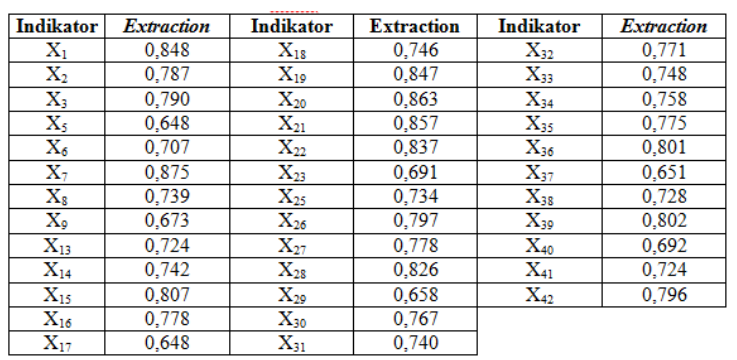

Sumber : Hasil Penelitian, 2016 (diolah)

4. Eigenvalue, yaitu nilai yang menunjukkan jumlah varian-varian yang berasosiasi dengan masingmasing faktor. Faktor yang mempunyai eigenvalue satu, yang dimasukkan dalam model, sedangkan yang nilainya kurang dari satu merupakan 
Pratita, et al/Jurnal Ekonomi Syariah Teori dan Terapan Vol.5 No.7 Juli 2018: 522-540; FAKTOR YANG MEMPENGARUHI KEPUTUSAN NASABAH MENABUNG DI BANK MUAMALAT INDONESIA

faktor yang tidak dimasukkan dalam model. Apabila eigenvalue lebih besar dari satu maka semakin representatif faktor tersebut mewakili indikator.

Hasil penelitian pada Tabel 4 menunjukkan komponen faktor yang terbentuk ada delapan. Ini menunjukkan ada 8 faktor yang terbentuk dari hasil rotasi faktor. Komponen faktor berhenti pada nilai eigenvalue sebesar 1,147.

\section{Tabel 4}

Nilai Eigenvalue dan \% Variance

\section{Explained}

\begin{tabular}{|l|c|c|c|c|c|c|}
\hline \multirow{2}{*}{ Component } & \multicolumn{3}{|c|}{ Initial Eigenvalues } & \multicolumn{3}{c|}{ Rotation Sums of Squared Loadings } \\
\cline { 2 - 7 } & Total & $\begin{array}{c}\% \text { of } \\
\text { Variance }\end{array}$ & Cumulative \% & Total & $\begin{array}{c}\% \text { of } \\
\text { Variance }\end{array}$ & Cumulative \% \\
\hline 1 & 16,233 & 43,873 & 43,873 & 6,353 & 17,170 & 17,170 \\
\hline 2 & 2,988 & 8,076 & 51,949 & 4,373 & 11,818 & 28,988 \\
\hline 3 & 2,166 & 5,853 & 57,802 & 4,327 & 11,695 & 40,683 \\
\hline 4 & 1,696 & 4,583 & 62,385 & 3,740 & 10,109 & 50,792 \\
\hline 5 & 1,521 & 4,110 & 66,495 & 3,077 & 8,317 & 59,110 \\
\hline 6 & 1,251 & 3,382 & 69,877 & 2,476 & 6,692 & 65,802 \\
\hline 7 & 1,150 & 3,107 & 72,984 & 2,075 & 5,607 & 71,409 \\
\hline 8 & 1,147 & 3,101 & 76,085 & 1,730 & 4,676 & 76,085 \\
\hline
\end{tabular}

Sumber : Hasil Penelitian, 2016 (diolah)

Percentage of variance, yaitu total dari varians yang dapat dijelaskan oleh aribut-atribut dari masing-masing faktor sebesar $76,085 \%$. Nilai ini lebih dari $50 \%$ sehingga faktor yang terbentuk dari proses analisis faktor dapat diterima.

Faktor matrix, yaitu faktor yang berisi muatan faktor dari semua indikator pada semua faktor yang telah dipilih. Dari faktor matrix ini dapat dilihat pengaruh dari indikator terhadap faktor. Hasil perhitungan component matriks dapat dilihat pada Tabel 5 pada halaman yang menunjukkan ada delapan faktor yang terbentuk. Dalam komponen matriks yang dapat diinterpretasikan apabila mempunyai nilai loading faktor lebih dari 0,5 . Pada faktor pertama yang mempunyai nilai lebih dari 0,5 yaitu $X_{1}, X_{2}$,
$X_{3}, X_{5}, X_{6}, X_{7}, X_{8}, X_{9}, X_{13}, X_{14}, X_{15}, X_{16}, X_{18}, X_{19}$, $X_{20}, X_{21}, X_{22}, X_{23}, X_{26}, X_{27}, X_{28}, X_{29}, X_{31}, X_{32}, X_{33}$, $x_{34}, x_{35}, x_{36}, x_{38}$. faktor kedua yang mempunyai nilai lebih dari 0,5 pada indikator $X_{37}, X_{39}, X_{40}, X_{41}, X_{42}$. Kemudian untuk faktor keempat yang mempunyai nilai lebih dari 0,5 pada indikator $X_{15}$.

Tabel 5

Hasil Perhitingan Komponen Matrik

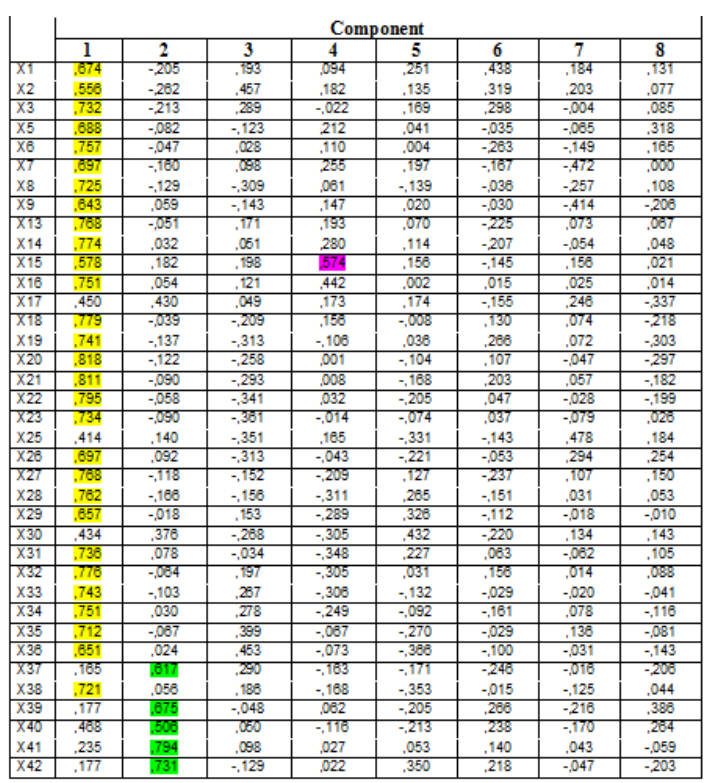

Sumber : Hasil Penelitian, 2016 (diolah)

Tujuan rotasi faktor adalah agar matriks faktor menjadi lebih sederhana dan menyebar dalam beberapa faktor yang berbeda sehingga lebih mudah diinterpretasikan. Indikator-indikator yang termasuk kedalam suatu faktor harus memiliki loading faktor diatas 0,5 sedangkan dibawah 0,5 dibuang atau tidak dimasukkan kedalam faktor.

\section{Tabel 6}


Hasil perhitungan rotasi faktor

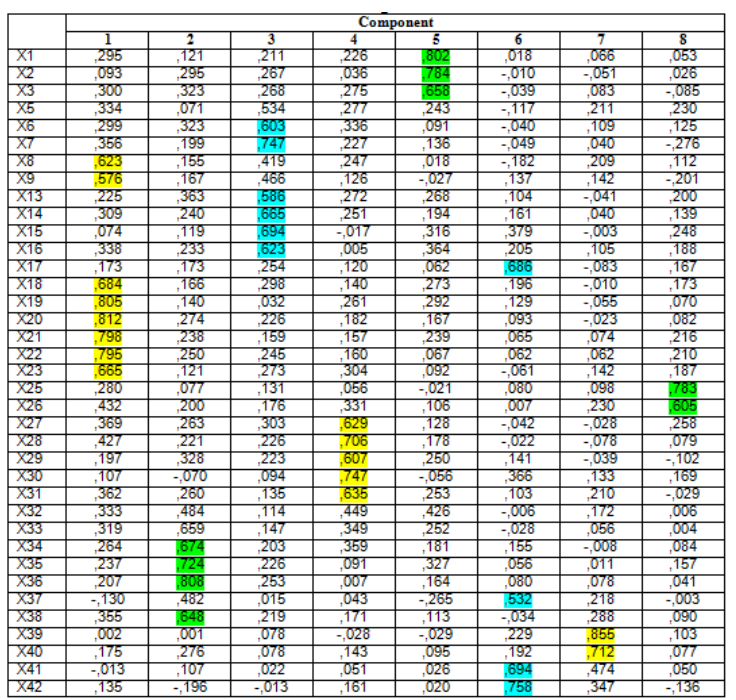

Sumber : Hasil Penelitian, 2016 (diolah)

Hasil perhitungan rotasi faktor menunjukkan ada 8 faktor yang terbentuk. Dalam rotasi faktor yang dapat diinterprestasikan adalah apabila mempunyai nilai loading faktor lebih dari 0,5 .

1. Faktor pertama yang mempunyai nilai lebih dari 0,5 pada indikator $X_{8}, X_{9}, X_{18}$, $\mathrm{X}_{19}, \mathrm{X}_{20}, \mathrm{X}_{21}, \mathrm{X}_{22}$, dan $\mathrm{X}_{23}$.

2. Faktor kedua yang mempunyai nilai lebih dari 0,5 pada indikator $X_{34}, X_{35}$, $X_{36}$ dan $X_{38}$.

3. Faktor ketiga yang mempunyai nilai lebih dari 0,5 pada indikator $X_{6}, X_{7}, X_{13}$, $\mathrm{X}_{14}, \mathrm{X}_{15}$ dan $\mathrm{X}_{16}$

4. Faktor keempat yang mempunyai nilai lebih dari 0,5 pada indikator $X_{27}, X_{28}$, $\mathrm{X}_{29}, \mathrm{X}_{30}$ dan $\mathrm{X}_{31}$.

5. Faktor kelima yang mempunyai nilai lebih dari 0,5 pada indikator $\mathrm{X}_{1}, \mathrm{X}_{2}$ dan $X_{3}$.

6. Faktor keenam yang mempunyai nilai lebih dari 0,5 pada indikator $X_{17}, X_{37} X_{41}$ dan $\mathrm{X}_{42}$.
7. Faktor ketujuh yang mempunyai nilai lebih dari 0,5 pada indikator $X_{39}$ dan $X_{40}$.

8. Faktor kedelapan yang mempunyai nilai lebih dari 0,5 pada indikator $X_{25}$ dan $\mathrm{X}_{26}$.

Faktor pertama yang mempunyai nilai lebih dari 0,5 pada indikator $X_{8}, X_{9}, X_{18}$, $X_{19}, X_{20}, X_{21}, X_{22}$, dan $X_{23}$. Nilai loading faktor tertinggi terletak pada indikator ke-21 $\left(X_{21}\right)$ dengan nilai loading 0,917. Indikator tersebut mengenai kinerja Karyawan BMI yang menjelaskan produk dengan sabar dan telaten kepada nasabah. Berdasarkan indikator tersebut maka disebut atau dinamai dengan faktor penyedia layanan.

Faktor kedua yang mempunyai nilai lebih dari 0,5 pada indikator $X_{34}, X_{35}, X_{36}$, dan $X_{38}$. Nilai loading faktor tertinggi terletak pada indikator ke-34 (X34) dengan nilai loading 0,930. Indikator tersebut mengenai kesesuaian Produk Tabungan BMI dengan ajaran Agama Islam. Berdasarkan indikator tersebut maka disebut atau dinamai dengan faktor persepsi normatif.

Faktor ketiga yang mempunyai nilai lebih dari 0,5 pada indikator $X_{6}, X_{7}, X_{13}, X_{14}$, $X_{15}$, dan $X_{16}$. Nilai loading faktor tertinggi terletak pada indikator ke-14 (X14) dengan nilai loading 0,920 . Indikator tersebut mengenai Biaya administrasi yang ditetapkan BMI masih dalam batas jangkauan nasabah. Berdasarkan indikator tersebut maka disebut atau dinamai dengan faktor kejelasan informatif. 
Pratita, et al/Jurnal Ekonomi Syariah Teori dan Terapan Vol.5 No.7 Juli 2018: 522-540; FAKTOR YANG MEMPENGARUHI KEPUTUSAN NASABAH MENABUNG DI BANK MUAMALAT INDONESIA

Faktor keempat yang mempunyai nilai lebih dari 0,5 pada indikator $X_{28}, X_{29}$, $X_{30}$, dan $X_{31}$. Nilai loading faktor tertinggi terletak pada indikator ke-28 (X28) dengan nilai loading 0,837 . Indikator tersebut mengenai proses pendaftaran internet-banking BMI mudah. Berdasarkan indikator tersebut maka disebut atau dinamai dengan faktor proses transaksi.

Faktor kelima yang mempunyai nilai lebih dari 0,5 pada indikator $X_{1}, X_{2}$. dan $X_{3}$. Nilai loading faktor tertinggi terletak pada indikator ke-2 (X2) dengan nilai loading 0,892 . Indikator tersebut mengenai kehalal-an produk tabungan BMI. Berdasarkan indikator tersebut maka disebut atau dinamai dengan faktor nilai syariah produk.

Faktor keenam yang mempunyai nilai lebih dari 0,5 pada indikator $X_{17}, X_{37}$, $X_{41}$, dan $X_{42}$. Nilai loading faktor tertinggi terletak pada indikator ke-17 (X17) dengan nilai loading 0,815. Indikator tersebut mengenai kesesuaian produk tabungan BMI dengan jabatan yang dimiliki nasabah. Berdasarkan indikator tersebut maka disebut atau dinamai dengan faktor referral.

Faktor ketujuh yang mempunyai nilai lebih dari 0,5 pada indikator $\mathrm{X}_{39}$, dan $\mathrm{X}_{40}$. Nilai loading faktor tertinggi terletak pada indikator ke-40 (X40) dengan nilai loading 0,846 . Indikator tersebut mengenai menabung di BMl karena pengaruh lingkungan kerja / sekolah / kampus. Berdasarkan indikator tersebut maka disebut atau dinamai dengan faktor kesesuaian lingkungan.
Faktor kedelapan yang mempunyai nilai lebih dari 0,5 pada indikator $X_{25}$, dan $X_{26}$. Nilai loading faktor tertinggi terletak pada indikator ke-26 (X26) dengan nilai loading 0,892 . Indikator tersebut mengenai penampilan kantor $\mathrm{BMI}$ yang menarik perhatian nasabah dengan nuansa ungu dan hijau. Berdasarkan indikator tersebut maka disebut atau dinamai dengan faktor layout design kantor.

Tabel 7.

Hasil Uji Validitas dan Reliabilitas Konfirmasi Hasil Analisis Faktor

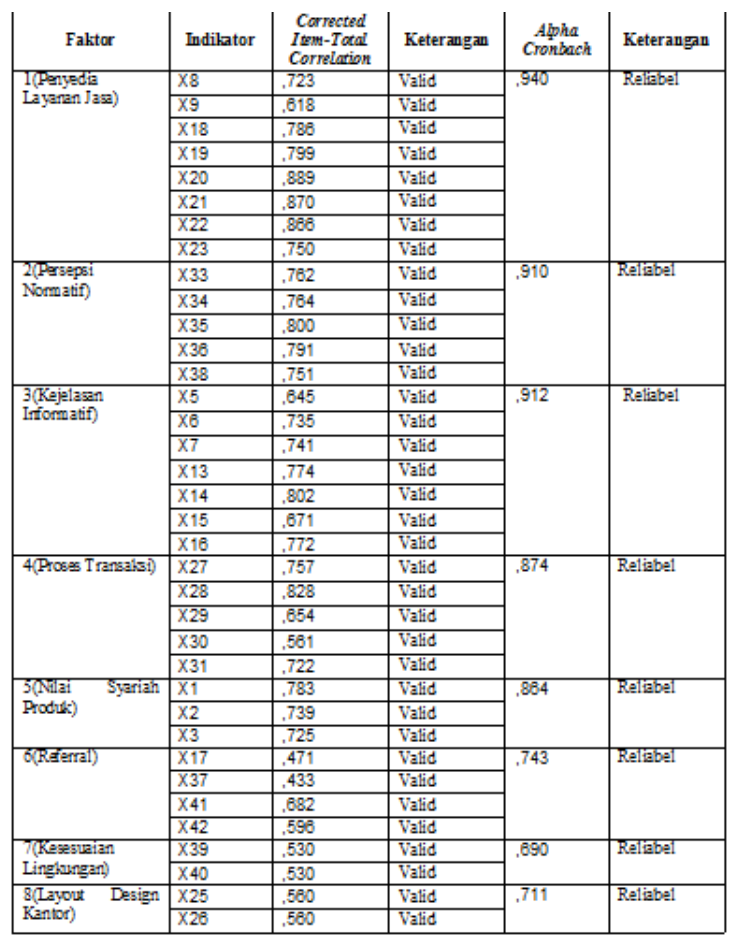

Sumber : Hasil Penelitian, 2016 (diolah)

Berdasarkan dimensi baru yang terbentuk setelah dilakukannya exploratory factor analysis maka indikator pernyataan dalam mendeskripsikan faktor yang ada pada penelitian seluruhnya reliabel. Hasil perhitungan ternyata menunjukkan bahwa semua indikator reliabel sehingga faktor yang terbentuk dan memenuhi syarat reliabel sebagai 
Pratita, et al/Jurnal Ekonomi Syariah Teori dan Terapan Vol.5 No.7 Juli 2018: 522-540; FAKTOR YANG MEMPENGARUHI KEPUTUSAN NASABAH MENABUNG DI BANK MUAMALAT INDONESIA

faktor yang berpengaruh pada keputusan nasabah menabung di Bank Muamalat Indonesia Surabaya ada delapan, yaitu faktor pelayanan perbankan, kesesuaian normatif, kejelasan informatif, Proses, nilai syariah produk, strata sosial, kongruensi lingkungan dan infrastruktur kantor.

\section{PEMBAHASAN}

\section{A. Faktor penyedia layanan}

Faktor pelayanan bank dalam penelitian ini disusun oleh delapan indikator. Faktor pelayanan Bank merupakan faktor yang dipertimbangkan oleh nasabah ketika memilih suatu perusahaan perbankan untuk menabung. Menurut Kasmir (2003:216) Customer Service secara umum adalah setiap kegiatan yang diperuntukan atau ditujukan untuk memberikan kepuasan kepada nasabah, melalui pelayanan yang dapat memenuhi keinginan dan kebutuhan nasabah. Selain Ratnasari-Aksa dan Kasmir, Kotler (2002;143) juga menyatakan bahwa pelayanan atau service adalah setiap kegiatan atau manfaat yang dapat diberikan suatu pihak kepada pihak lain nya yang pada dasarnya tidak berwujud dan tidak pula berakibat pemilikan sesuatu dan produksinya dapat atau tidak dapat dikaitkan dengan suatu produk fisik. Dalam Ekonomi Islam, keputusan akan suatu pilihan harus didasarkan pada AlQur'an atau hadist. Pelayanan jasa yang baik dalam bidang ekonomi ini selaras dengan ayat Al-Quran Surat Ali Imran ayat 159:

Artinya: Maka disebabkan rahmat dari Allah-lah kamu Berlaku lemah lembut terhadap mereka. Sekiranya kamu bersikap keras lagi berhati kasar, tentulah mereka menjauhkan diri dari sekelilingmu. karena itu ma'afkanlah mereka, mohonkanlah ampun bagi mereka, dan bermusyawaratlah dengan mereka dalam urusan itu

Berdasarkan fakta di lapangan, nasabah memilih suatu bank berdasarkan pengalaman mengenai pelayanan yang baik yang diberikan oleh karyawan BMI. Nasabah BMI yang berasal dari kalangan menengah merasa sangat terbantu dengan adanya pelayanan yang mempermudah terkait ketentuan setoran awal ringan dan saldo minimum pada rekening nasabah sehingga para nasabah yang masih awam mengenai perbankan syariah bisa mendapatkan layanan jasa perbankan syariah yang sama. Selain pelayanan yang mempermudah terkait prosedural mengenai rekening, nasabah juga dibuat senyaman mungkin saat berada di ruang tunggu. Kenyaman tersebut tercipta ketika nasabah memasuki kantor BMI, para security memberikan salam kemudian menanyakan keperluan nasabah dan mempersilahkan nasabah untuk ke ruang tunggu dengan sopan. Pelayanan Bank disini menjelaskan bagaimana cara dari para karyawan selaku front-liner (customer service,teller dan security) memberikan citra yang baik dan membuat nasabah merasa nyaman 
Pratita, et al/Jurnal Ekonomi Syariah Teori dan Terapan Vol.5 No.7 Juli 2018: 522-540; FAKTOR YANG MEMPENGARUHI KEPUTUSAN NASABAH MENABUNG DI BANK MUAMALAT INDONESIA

ketika bertransaksi di kantor kas BMI Surabaya.

\section{B. Faktor persepsi normatif}

Faktor persepsi dalam penelitian ini disusun berdasarkan empat indikator. Indikator tersebut adalah menabung di BMI karena sesuai dengan pemahaman saya akan Bank Syariah ( $\left.x_{34}\right)$, menabung di BMI karena sesuai dengan ekspektasi saya akan Bank Syariah ( $x_{35}$ ), menabung di BMI karena sesuai dengan ajaran Agama Islam $\left(x_{36}\right)$, menabung di BMI karena ingin menjalani perilaku dan gaya hidup yang islami ( $\left.x_{38}\right)$. Dari keempat indikator itu memiliki kesamaan yaitu keingin untuk menjalakan sesuatu yang mengarah pada persepsi.

Berdasarkan fakta dilapangan, sebagian besar nasabah BMI memutuskan untuk menabung di BMl karena adanya dorongan kuat yang terbentuk dari norma-norma yang ada dilingkungan sekitar mereka. Suatu individu atau kalangan yang sangat berpegang teguh kepada norma kehidupan yang terbentuk dalam masyarakat membuat norma tersebut menjadi sebuah pertimbangan yang sangat penting dan berpengaruh kepada nasabah secara normatif. Normatif disini lebih mengarah ke norma agama yang dibentuk berdasarkan nilainilai agama yang sudah ditanamkan sejak dini disuatu lingkungan. Nasabah BMI merasa bahwa produk tabungan dari BMI sudah sesuai dengan ajaran Agama Islam. Selain sesuai dengan ajaran Agama
Islam, produk dari BMI juga sudah kepribadian mereka yang islami.

Setiap nasabah pasti memiliki ekspektasi tertentu terhadap suatu produk yang mereka gunakan. Salah satu alasan mengapa nasabah BMI memilih menabung di BMI karena merasa bahwa Produk tabungan dari BMI sudah memenuhi ekspektasi mereka mengenai tabungan bersistem syariah. Nasabah BMI juga menabung di BMI karena adanya dorongan dari dalam diri mereka untuk menjalani gaya hidup yang islami, termasuk salah satunya dalam bidang ekonomi.

\section{Faktor Kejelasan Informatif}

Faktor kejelasan informatif dalam penelitian ini dibentuk dari enam indikator. Keenam indikator tersebut cenderung mengarah kepada informasi mengenai produk BMI khususnya tabungan, apa dan bagaimana nasabah mendapatkan informasinya.

Teori Elaboration Likelihood Model (ELM) yang di kembangkan oleh Petty dan Cacioppo (1986) menjelaskan dua jalur proses kognitif individu dalam memikirkan pesan. Dua jalur tersebut adalah jalur sentral (central route) dan jalur periferal (peripheral route) (Griffin, 2004). Pemrosesan informasi atau pesan melalui jalur sentral ditandai dengan adanya kecermatan, pemikiran mendalam, dan pemrosesan informasi secara sistematis. Sedangkan pemrosesan informasi melalui jalur periferal lebih 
Pratita, et al/Jurnal Ekonomi Syariah Teori dan Terapan Vol.5 No.7 Juli 2018: 522-540; FAKTOR YANG MEMPENGARUHI KEPUTUSAN NASABAH MENABUNG DI BANK MUAMALAT INDONESIA

mengarah pada isyarat jeuristik seperti sumber yang individu memiliki motivasi dan kemampuan yang rendah dalam memproses informasi. Dengan demikian apabila individu dalam menerima pesan berfokus pada isi pesan maka individu tersebut menggunakan jalur sentral dalam memproses informasi. Apabila individu lebih memperhatikan daya tarik pesan lainnya seperti gambar, humor, atau penyampai pesan maka individu tersebut menggunakan jalur periferal dalam memproses informasi (Petty \& Cacioppo, 1990).

Berdasarkan fakta di lapangan, sebagian besar nasabah menyatakan bahwa mereka merasa terbantu dengan adanya brosur, website dan layanan informasi lainnya dari BMl yang memudahkan nasabah untuk mendapatkan informasi. berdasarkan teori ELM, nasabah memproses informasi tersebut melalui jalur sentral dimana nasabah memperhatikan lebih kepada isi dari informasi tersebut dan mempertimbangkan cermat dan mendalam. Informasi tersebut mencakup persyaratan, ketentuan serta proses saat bertransaksi. Nasabah juga menyatakan terbantu dengan adanya informasi mengenai biaya administrasi maupun tingkat bagi hasil yang diberikan BMI kepada nasabah berdasarkan jenis tabungan yang dipilih oleh nasabah, sehingga nasabah merasa nyaman menabung karena telah mengetahui syarat dan ketentuan yang berlaku.

\section{Faktor Proses}

Faktor proses dalam penelitian ini trbentuk dari lima indikator. Menurut Sumarwan (2011:19), Proses adalah bagaimana suatu jasa disampaikan dan dikonsumsi oleh konsumen. Ketika jasa dikonsumsi konsumen, seringkali membutuhkan proses yang harus diikuti oleh konsumen dan orang-orang yang terlibat dalam memberikan jasa kepada konsumen. Berdasarkan fakta di lapangan, sebagian nasabah BMI merasakan adanya kemudahan dalam melakukan transaksi dengan proses yang cepat dan tidak berbelit-belit. Beberapa nasabah BMI juga menyatakan bahwa sebelum menjadi nasabah di BMl, adanya satu proses dimana pihak bank menanyakan terlebih dahulu apa yang menjadi kebutuhan ekonomi calon nasabah dan menyesuaiakan kebutuhan calon nasabah dengan produk yang dimiliki BMI.

\section{E. Faktor Nilai Syariah Produk}

Faktor Nilai Syariah Produk dalam penelitian ini terbentuk dari tiga indikator. Indikator tersebut berhubungan kuat dengan unsur syariah yang dimiliki suatu produk tabungan. Menurut fatwa DSN MUI no 2 tahun 2000 tentang tabungan, menjelaskan bahwa tabungan yang dibenarkan dalam syar'iyah adalah tabungan dengan akad mudharabah dan wadiah. Fatwa tersebut juga menjelaskan poin-poin inti yang membedakan tabungan syariah dan non- 
Pratita, et al/Jurnal Ekonomi Syariah Teori dan Terapan Vol.5 No.7 Juli 2018: 522-540; FAKTOR YANG MEMPENGARUHI KEPUTUSAN NASABAH MENABUNG DI BANK MUAMALAT INDONESIA

syariah dengan pertimbangan dari ayat dan hadist yang telah ada. Dalam QS AlBaqarah 278 dan Ali-Imron 130, menjelaskan tentang adanya ajakan dan perintah untuk menjauhi riba, sebagai berikut

Artinya : Hai orang-orang yang beriman, bertakwalah kepada Allah dan tinggalkan sisa Riba (yang belum dipungut) jika kamu orang-orang yang beriman.

Ali-Imron 130

Artinya : Hai orang-orang yang beriman, janganlah kamu memakan Riba dengan berlipat ganda[228]] dan bertakwalah kamu kepada Allah supaya kamu mendapat keberuntungan.

Berdasarkan fakta di lapangan, sebagian besar nasabah BMI memilih tabungan di BMI karena mempresepsi adanya kepastian kemurnian syariah dalam produk tersebut, dimana produk tabungan tersebut tidak memiliki unsur riba' (sistem berbasis bunga), tabungan sesuai prosedur syariah bermuamalah, dan sejak awal akad sudah disesuaikan dengan fatwa DSN MUI.

\section{F. Faktor Referral}

Faktor strata sosial dalam penelitian ini dibentuk dari empat indikator. Menurut Kotler dalam Simamora (2008:8-9), kelas sosial adalah susunan yang relatif permanen dan teratur dalam suatu masyarakat yang anggotanya mempunyai nilai, minat, dan perilaku yang sama. Kelas sosial tidak ditentukan oleh faktor tunggal seperti pendapatan tetapi diukur sebagai kombinasi pekerjaan, pendapatan, pendidikan, kekayaan, dan variabel lainnya. Kelas sosial memperlihatkan preferensi produk dan merek yang berbeda.

Berdasarkan fakta di lapangan, saat ini BMI sedang bekerja sama dengan PT Citilink Indonesia dan PT Indosat Ooredoo dengan mengadakan promo saat bertransaksi menggunakan Bank Muamalat Indonesia. Perusahaan yang sedang maupun sudah bekerjasama dengan BMI adalah perusahaan yang sudah dikategorikan kelas menengah ke atas seperti PT Telkomsel dan PT Indosat Ooredoo.

Selain adanya kerjasama menarik dengan pihak merchant, pengaruh dari keluarga atau kerabat yang sudah terlebih dahulu menjadi nasabah cukup dipertimbangkan oleh nasabah dengan alasan adanya rasa nyaman dan tenang karena melakukan transaksi dengan saudara atau kerabat di bank yang sama. Sesuai dengan pernyataan dari Kotler dalam Simamora (2008), latar belakang pendidikan, pendapatan, posisi jabatan, dan variabel lainnya mampu mengubah preferensi nasabah pada suatu produk yang juga akan menjadikan beberapa produk terkelas menjadi atas,menengah dan bawah.

\section{G. Faktor Kesesuaian Lingkungan}

Faktor kongruensi lingkungan dalam penelitian ini terbentuk dari dua indikator. 
Pratita, et al/Jurnal Ekonomi Syariah Teori dan Terapan Vol.5 No.7 Juli 2018: 522-540; FAKTOR YANG MEMPENGARUHI KEPUTUSAN NASABAH MENABUNG DI BANK MUAMALAT INDONESIA

Kedua indikator tersebut berhubungan kuat mengenai lingkungan yang bertindak sebagai faktor luar yang mampu mempengaruhi keputusan konsumen akibat adanya interaksi secara langsung maupun tidak langsung dengan pihak lain.

Kongruensi sendiri memiliki arti keselarasan, sedangkan kongruensi lingkungan adalah adanya keselarasan atau keseimbangan dengan lingkungan. Pengaruh lingkungan merupakan faktor eksternal yang mampu mempengaruhi keputusan pembelian atau konsumsi seseorang. Faktor lingkungan sendiri terbagi menjadi beberapa kelompok dimana salah satunya adalah kelompok tatap muka (face-to-face group). Kelompok tatap muka sendiri dibagi lagi menjadi tiga kelompok yaitu referensi, keluarga dan teman. Menurut Kotler, (2003:184), Kelompok referensi adalah kelompok yang memberikan pengaruh langsung dan tidak langsung terhadap sikap dan perilaku seseorang.

Berdasarkan fakta di lapangan, beberapa nasabah BMI menyatakan bahwa menabung di BMI karena adanya pertimbangan setelah berinteraksi dengan teman atau kerabat dilingkungan kerja/sekolah/kampus mengenai produk tabungan di BMI. Lingkungan sekolah/kampus/kerja sendiri merupakan sarana terjalinnya hubungan antar individu sehingga mampu terbentuk satu atau lebih kelompok. Kelompok tersebut dapat disebut sebagai kelompok referensi.

\section{H. Faktor Layout Design Kantor}

Faktor infrastruktur kantor dalam penelitian ini terbentuk dari dua indikator. Kedua indikator tersebut meliputi lingkungan fisik dari kantor pelayanan BMI. Lingkungan fisik adalah keadaan atau kondisi yang di dalamnya juga termasuk suasana kantor yang merupakan tempat beroperasinya jasa layanan perbankan. Karakteristik lingkungan fisik merupakan segi paling nampak dalam kaitannya dengan situasi. Yang dimaksud dengan situasi ini adalah situasi dan kondisi geografi dan lingkungan institusi, dekorasi, ruangan, suara, aroma, cahaya, cuaca, pelatakan dan layout yang nampak atau lingkungan yang penting sebagai obyek stimuli (Belk 1974 dalam Assael 1992).

Berdasarkan fakta di lapangan, Nasabah BMI menyatakan bahwa tata ruang kantor yang rapi dan nyaman mampu menciptakan suasana yang menenangkan membuat nasabah lebih merasa nyaman saat bertransaksi di kantor. Selain penataan ruangan yang rapi dan nyaman, nasabah BMl juga menyadari adanya perabot dan hiasan ruangan bernuansa ungu dan hijau. Susanto dan Wijanarko (2004:17) menyatakan bahwa merek sering didefinisikan sebagai serangkaian huruf, simbol, angka, atau konfigurasi warna sebagai 'tanda' untuk membedakan suatu produk dengan produk lain. Hal ini 
Pratita, et al/Jurnal Ekonomi Syariah Teori dan Terapan Vol.5 No.7 Juli 2018: 522-540; FAKTOR YANG MEMPENGARUHI KEPUTUSAN NASABAH MENABUNG DI BANK MUAMALAT INDONESIA

juga disebut sebagai Brand Mark atau tanda merek dimana sebagian dari merek yang dapat mudah dikenali namun tidak dapat diucapkan, seperti lambang, desain huruf atau warna. Warna hijau dan ungu sudah menjadi identitas BMI, hal itu terlihat dari penulisan dan pewarnaan yang terdapat di logo BMI.

\section{SIMPULAN}

1. Faktor yang mempengaruhi keputusan nasabah menabung di Bank Muamalat Indonesia terbentuk sebanyak delapan faktor. Faktor yang terbentuk dinamai dengan faktor penyedia layanan jasa, faktor persepsi, faktor kejelasan informatif, faktor proses transaksi, faktor nilai syariah produk, faktor referral, faktor kesesuaian lingkungan dan faktor layout design kantor.

2. Faktor dengan nilai loading tertinggi yang didapat dari hasil perhitungan rotasi faktor adalah indikator $X_{7}$ pada faktor kejelasan informatif yaitu mengenai adanya informasi secara jelas yang disediakan Bank Muamalat Indonesia mengenai produkproduknya. Hal ini menunjukkan bahwa setiap indikator dari semua faktor yang terbentuk dari keputusan konsumen secara tidak disadari selalu memperhatikan aspek kejelasan informasi saat memilih menggunakan jasa keuangan di Bank Muamalat Indonesia yang salah satunya adalah produk tabungan.

\section{DAFTAR PUSTAKA}

Alamsyah, Halim. 2012, Perkembangan dan Prospek Perbankan Syariah, Indonesia. IAEI.

Anshori Muslich dan Sri Iswati. 2009. Buku Ajar Metodologi Penelitian Kuantitatif. Surabaya: Pusat Penerbitan dan Percetakan UNAIR (AUP).

Antonio, Muhammad Syafii. 2001, Bank Syariah Dari Teori ke Praktek. Gema Insani Press bekerja sama dengan Yayasan Tazkia Cendekia.

Assael, Henry. 1998. Consumer Behavior and Marketing Action. Sixth Edition. Massachussets: Kent Publishing Company.

Departemen Agama RI. 2011. Al-Qur'an

Gitosudarmo, Indriyo. 2004. Manajemen Pemasaran. Edisi Pertama Cetakan Keenam.BPFE-Yogyakarta.

Kotler, Philip dan AB. Susanto.2001. Manajemen Pemasaran Indonesia. Buku 2.Salemba empat. Jakarta.

John Bowen and James Makens. 2002. Pemasaran Perhotelan dan Kepariwisataan.Edisi 2. Jakarta: PT Prenhallindo.

2004. Prinsip-prinsip Pemasaran Jilid II. Jakarta: Erlangga.

-------, dan Kevin Lane Keller. 2009. Manajemen Pemasaran. Edisi 14. Jakarta: Erlangga.

Malhotra, Naresh K. 2010. Riset pemasaran: Pendekatan Terapan. Jilid 1. Jakarta: PT. Indeks.

Ratnasari, Ririn Tri. 2012. Konsep Dasar Syariah Marketing.Slide kuliah Manajemen Pemasaran Syariah. Pertemuan 1.Departemen Ekonomi Islam Fakultas Ekonomi dan Bisnis Universitas Airlangga.

2012. Manajemen Pemasaran Islam. Modul 1. Surabaya: Departemen 
Ekonomi Syariah Fakultas Ekonomi dan Bisnis Universitas Airlangga.

dan Nisful Laila. 2012. Measuring Customer Service Quality Based on Fatanah Implementation. Proceedings of 2nd Global Islamic Marketing Conference

(GIMC). Abu Dhabi.

Ratnawati, Anny. 2011."Potensi dan Strategi Pengembangan Bank Syariah di Indonesia",vol.9, no. 2.

Sugiyono.2010. Metode Penelitian Kuantitatif Kualitatif. Bandung: Alfabeta.

Sutisna.2001. Perilaku Konsumen dan Komunikasi Pemasaran. Bandung: PT. Remaja Rosdakarya. 